\title{
DAMAGE CAUSED BY A WHEELED HARVESTER TO THE RESIDUAL TREES OF A PINUS STAND IN THE FIRST MECHANIZED MIXED THINNING
}

\author{
Carlos Cezar Cavassin Diniz ${ }^{1 *}$, Felipe Martins de Oliveira ${ }^{2}$, Romano Timofeiczyk Junior ${ }^{1}$, Renato Cesar \\ Gonçalves Robert ${ }^{3}$, Miguel Pesch Tramontini ${ }^{1}$, Fabio Cordeiro de Brito ${ }^{1}$
}

${ }^{1}$ Federal University of Paraná - UFPR, Department of Rural Economy and Extension, Curitiba, Paraná, Brazil carloscezardiniz@gmail.com*,romano.timo@gmail.com,miguelpesch@gmail.com, brito.fabiocordeiro@gmail.com ${ }^{2}$ FatiFajar Colleges - ULT/Fajar, Department of Forest Engineering, Jaguariaíva, Paraná, Brazil - eng.oliveirafm@gmail.com ${ }^{3}$ Federal University of Paraná - UFPR, Department of Forest Engineering and Technology, Curitiba, Paraná, Brazil - renatorobert@ufpr.br

Received for publication: 15/01/2019 - Accepted for publication: 15/04/2019

\begin{abstract}
Resumo
Danos causados pelo harvester de pneus nas árvores remanescentes de um povoamento de pinus no primeiro desbaste misto mecanizado. O objetivo desta pesquisa foi avaliar os danos causados nas árvores remanescentes de um povoamento de pinus submetido ao desbaste mecanizado com harvester. Os dados foram obtidos nas áreas operacionais de colheita da madeira em uma empresa florestal localizada no município de Inácio Martins, estado do Paraná, Brasil. O povoamento de pinus objeto do estudo possuía 11 anos, com ele submetido ao primeiro desbaste comercial. A operação de corte florestal foi realizada por um harvester, caracterizada pela retirada sistemática da $5^{\mathrm{a}}$ linha de plantio para dar acesso ao interior do povoamento, seguida de seletiva nos indivíduos demarcados nas duas linhas adjacentes às trilhas de tráfego. Foram avaliados os danos causados nas árvores remanescentes do povoamento em relação às suas quantidades, dimensões e localização em relação à trilha de operação do harvester, sendo os dados analisados por meio da técnica de análise multivariada Profile Analysis. Observou-se que $25 \%$ das árvores remanescentes sofreram algum tipo de injúria, valor considerado elevado, mas atual perante a literatura. Evidenciou-se que a seção da árvore com necessidade de maior alerta foi a base, pois nela foram observados danos em maior intensidade e dimensões, o que pode trazer prejuízos futuros ao povoamento. Foi demonstrada a necessidade de melhorias nos procedimentos operacionais.

Palavras-chave: Colheita da madeira; qualidade; injúrias.
\end{abstract}

\begin{abstract}
The objective of this study was to evaluate the damage caused to the remaining trees of a pinus stand submitted to mechanized thinning by a wheeled harvester. The data were obtained in the operational areas of timber harvesting in a forest company located in the city of Inácio Martins, in the state of Paraná, Brazil. The Pinus stand of the study was 11 years old, and was submitted to the first commercial thinning. The operation was performed by a harvester, characterized by the systematic removal of the 5th planting line to give access to the interior of the stand, followed by selective thinning in the individuals demarcated in the two lines adjacent to the traffic trails. The damage caused to the remaining trees of the stand regarding their numbers, dimensions and location in relation to the harvester's operation track was evaluated, and the data were analyzed using the Profile Analysis multivariate analysis technique. It was observed that $25 \%$ of the remaining trees suffered some kind of damage, being considered a high value, but current to the literature. It was evidenced that the section of the tree in need of greater alert was the base because damages in greater intensity and dimensions were observed to it, which can bring future losses to the stand. Thus, a need for improvements in operational procedures was demonstrated.

Keywords: Timber harvesting; quality; injuries.
\end{abstract}

\section{INTRODUCTION}

Thinning can be highlighted among the techniques used to manage planted forests for wood production in Brazil, which according to Schneider and Schneider (2008), makes it possible to aggregate individual volume, quality and diversity of wood uses in the remaining trees due to the lower competition for water, light and nutrients. It is important to emphasize that it can be applied in several ways, from semi-mechanized cutting with the use of chainsaws to mechanized.

The harvester is one of the main cutting machines used in Brazil for felling and processing wood in the cut to length system (OLIVEIRA, 2013; SANTOS et al., 2018). However, when it is decided to conduct the thinning of a forest using the mechanized method, it is necessary to plan it properly, since it can have high costs given its low productivity when compared to clear cutting operations. Authors such as Spinelli and Nati (2009)

FLORESTA, Curitiba, PR, v. 50, n. 3, p. 1547 - 1554, jul/set 2020

Diniz, C. C. C. et.al.

ISSN eletrônico 1982-4688

DOI: 10.5380/rf.v50 i3. 64331 
and Lopes et al. (2016) warned that the high costs are caused by the greater difficulty in mobility of the machines inside the stand due to the restricted spaces, which can cause a reduction in the operation's productivity.

Other aspects such as operator experience, individual stand volume, slope of the land, species characteristics, spacing, the assortments produced, and the cutting area lines can affect the productivity of thinning operations and cause variation in production costs (SEIXAS; BATISTA, 2014; BARBOSA et al., 2015). When analyzing these variables together with the objective of preserving the best individuals for the final cut, it is possible to understand that the machine traffic inside the stands submitted to this activity can cause negative impacts such as soil compaction and damage to the remaining trees (VASILIAUSKAS, 2001; LINEROS et al., 2003).

It is common to systematically withdraw the fifth row in pine stands located in the south of Brazil to allow machines such as harvesters and forwarders to have access to the stand and to cut and extract the wood. However, the use of large equipment to carry out this type of operation can cause severe damage to the remaining trees. When carrying out a study on the impacts caused by these two machines on the commercial thinning of pine in Chile, Lineros et al. (2003) observed that $12.3 \%$ of the remaining trees in the stand were damaged and suffered injuries to the crown and the lower section. Likewise, when studying two pine thinning models in southern Brazil, one with the systematic removal of the $5^{\text {th }}$ row and the other of the $7^{\text {th }}$, Cabral et al. (2018) found a high intensity of damaged trees in the plots in both thinning models, indicating the need to improve operational procedures.

It is noted that the use of large machines is limited due to the small space for their mobility (LOPES et al., 2018). Even with high technology and adaptations for this type of operation, the damage caused to the remaining trees in mechanized thinning is still common. It is important to remember that such damages can also cause qualitative and sanitary problems to the trees, since they are passages for fungi which directly affect the wood quality, causing significant economic losses (LINEROS et al., 2003).

Thus, the objective of this research was to evaluate the damage caused to the remaining trees of a Pinus taeda L. stand submitted to its first commercial mechanized thinning with a harvester in order to generate information which would enable mitigating the damage to the remaining trees, as well as the sustainability of operations.

\section{MATERIAL AND METHODS}

This work was carried out in a Pinus taeda L. stand submitted to its first commercial thinning, belonging to a forest-based company located in the municipality of Inácio Martins, Paraná, Brazil. The region's climate was classified as $\mathrm{Cfb}$ according to the Koppen Classification, with an average temperature of $17^{\circ} \mathrm{C}$ and an average annual rainfall of $1460 \mathrm{~mm}$. The studied stand information is shown in Table 1.

Table 1. Characterization of the study area.

Tabela 1. Caracterização da área de estudo.

\begin{tabular}{lc}
\hline \multicolumn{1}{c}{ Variables } & Value \\
\hline Planted species & Pinus taeda \\
Age of the stand (years) & 11 \\
Individual average volume $\left(\mathrm{m}^{3}\right)$ & 0.22 \\
Stand area (ha) & 972.49 \\
Spacing (m) & $3 \times 2$ \\
Mean declivity (degrees) & 4.18 \\
Density (trees/ha) & 1666 \\
Mean volume (m $\left.{ }^{3} / \mathrm{ha}\right)$ & 309.85 \\
Mean height $(\mathrm{m})$ & 17.9 \\
Mean diameter $(\mathrm{cm})$ & 22.5 \\
Percentage of trees removed $(\%)$ & 50 \\
\hline
\end{tabular}

The thinning model used by the company was characterized as combined, which according to Schneider and Schneider (2008) is the removal of trees from the stand in a systematic and selective way. Thus, the total removal of the $5^{\text {th }}$ line in systematic thinning was performed and selective removal of individuals demarcated in the two lines adjacent to the harvester traffic trails, totaling 50\% cutting and extraction of the trees in the stand (FIGURE 1). 


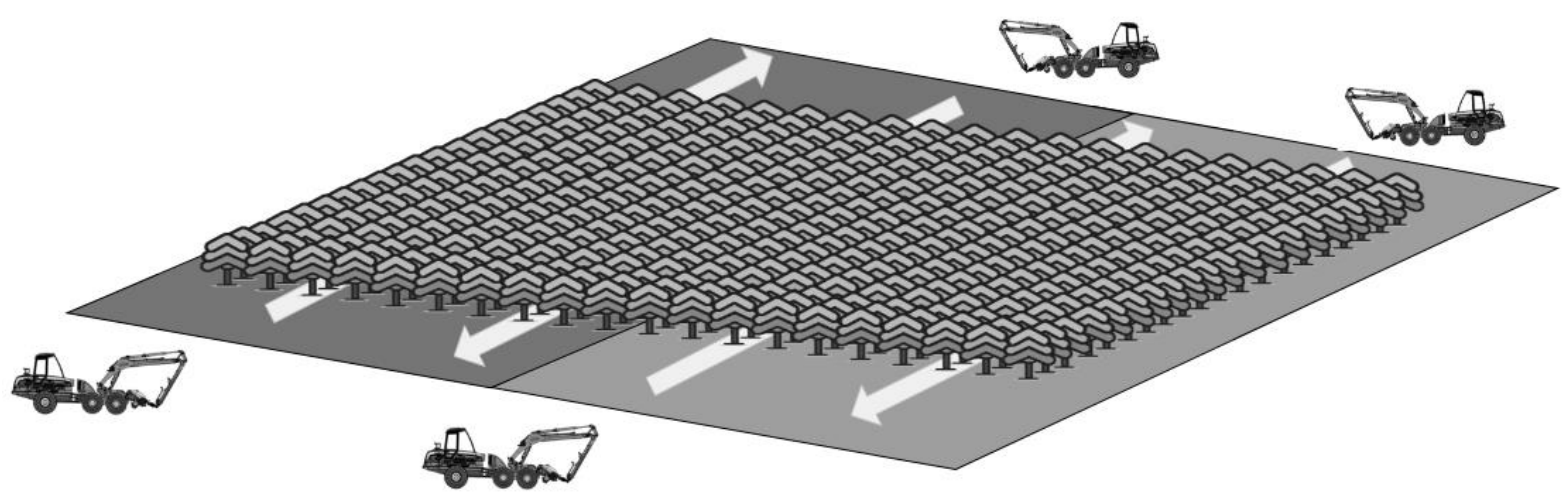

Figure 1. Execution scheme of the thinning.

Figura 1. Esquema da execução do desbaste.

A mechanized cut-to-length harvesting was used by the company. The forest cutting operation was carried out by a wheeled harvester, nominal power of $150 \mathrm{~kW}$, with a Mercedes-Benz/MTU engine OM 934 LA EU Stage IV, operating weight of 17.5 tons and 510.4 hours of work (FIGURE 2).

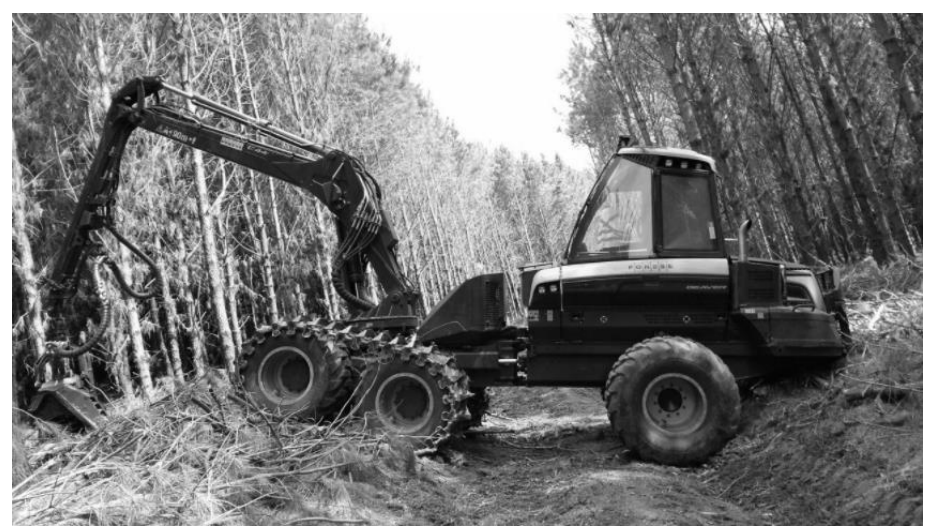

Figure 2. Harvester observed in this study.

Figura 2. Harvester observado nesta pesquisa.

Next, 24 plots of $13 \times 42 \mathrm{~m}$ were installed in two experimental areas of the studied stand (FIGURE 3). The classification of the Forestry Commission UK (1996) was used in relation to the relief, presenting flat terrain from $0^{\circ}$ to $6^{\circ}$ and smooth from $6.1^{\circ}$ to $11^{\circ}$. No major declivities were detected.
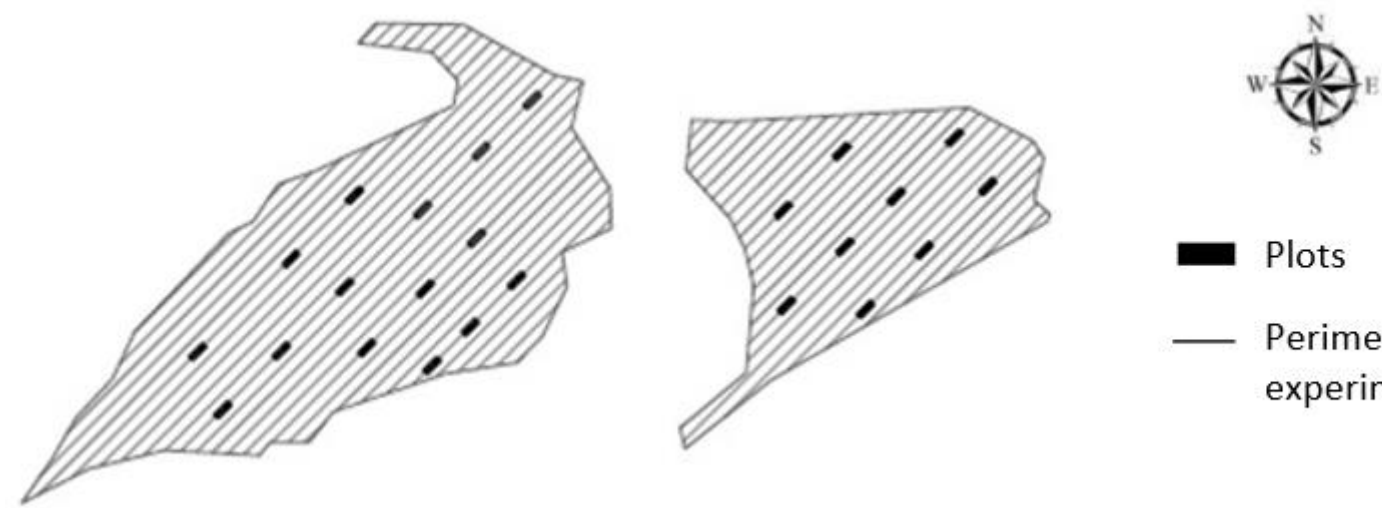

Figure 3. Location of plots in the study area.

Figura 3. Localização das parcelas na área de estudo.

FLORESTA, Curitiba, PR, v. 50, n. 3, p. 1547 - 1554, jul/set 2020.

Diniz, C. C. C. et.al.

ISSN eletrônico 1982-4688

DOI: 10.5380/rf.v50 i3. 64331 
The damaged area in the trees was obtained by measuring using a $1 \mathrm{~cm}^{2}$ grid, being classified as light $(\leq$ $\left.100 \mathrm{~cm}^{2}\right)$, moderate $\left(>100 \mathrm{~cm}^{2} \leq 200 \mathrm{~cm}^{2}\right)$ and intense $\left(>200 \mathrm{~cm}^{2}\right)$. An individual count was carried out within each sampled plot regarding the number of damaged trees and the location of the damage, and classified in three different heights: base damage $(\leq 1.3 \mathrm{~m})$, trunk/shaft damage $(>1.3 \mathrm{~m} \leq 6 \mathrm{~m})$ and crown damage $(>6 \mathrm{~m})$, according to guidelines by Lineros et al. (2003) and Cabral et al. (2018).

We also tried to detect the location of the damage in relation to the machine's working area (FIGURE 4). It is important to note that the data collection was performed right after performing the cutting operation with the harvester, without counting the damage from the subsequent operation (extraction with forwarder). The obtained results were submitted to the analysis of variance technique for completely randomized experiments using the $\mathrm{R}$ statistical software program (R-Statistics). A Tukey test at $5 \%$ probability was performed for cases in which there was a statistically significant difference.
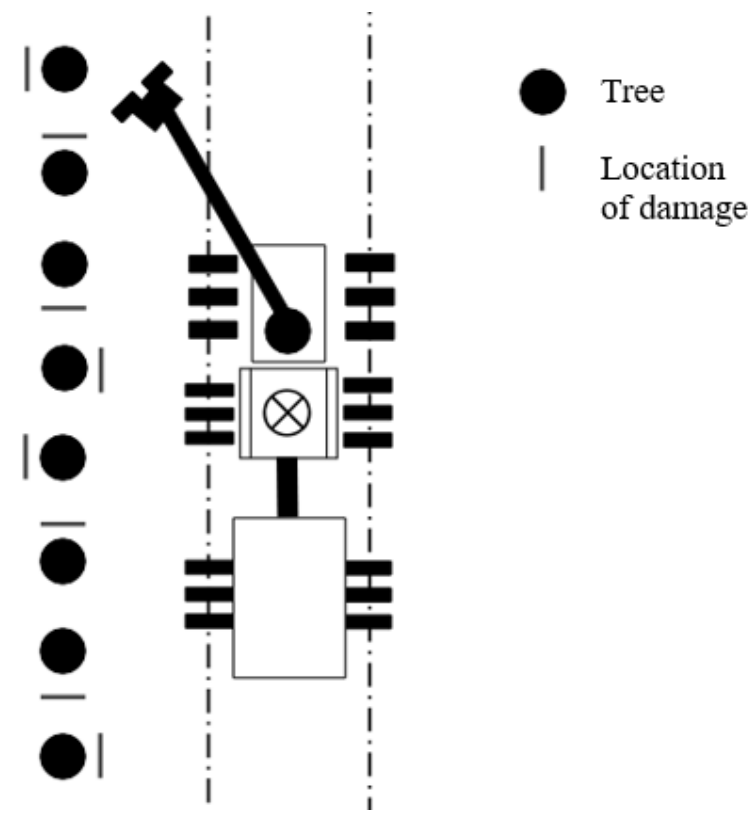

Figure 4. Possible locations of damage to the tree relative to the harvester.

Figura 4. Possíveis localizações de danos na árvore em relação ao harvester.

A statistical analysis was performed in order to test whether there were differences in the amount and size of damage to the three possible locations: base, trunk/shaft and crown. It was also verified whether there was a difference in relation to the types of relief found in the present study using the multivariate analysis technique called Profile Analysis, a test based on the technique presented by Johnson and Wichern (1988). Three hypotheses were tested at the level of $\alpha=5 \%$. First, the Parallelism Test, where it is ascertained whether the two curves have similarities to each other; the Levels Test was performed in the second hypothesis to examine which segment has the greatest contribution in damages; and third, the Test in Relation to the Plan, in which it is examined whether curves tend to be flat or sloped. The calculations were processed using Octave ${ }^{\circledR}$ software, the free version of Matlab $^{\circledR}$.

\section{RESULTS}

A total of 947 trees were obtained in the experimental plots after thinning. It was observed that $25 \%$ of the remaining trees suffered some type of injury, a value which is considered high. It is important to note that this situation occurred due to the irregular alignment of the planting in relation to the spacing, making it difficult to cut down and process the trees.

The average distribution of the damage size in relation to the location on the trees by type of terrain can be seen in Figure 5.

FLORESTA, Curitiba, PR, v. 50, n. 3, p. 1547 - 1554, jul/set 2020 


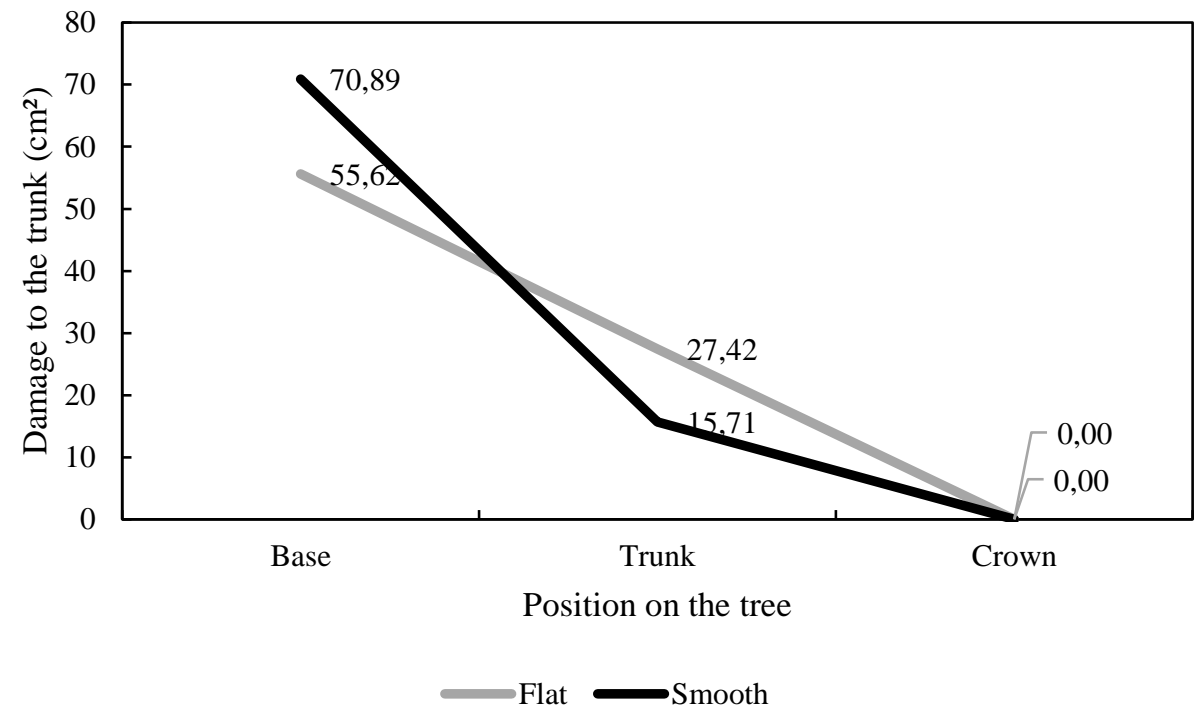

Figure 5. Mean size of damage caused by the harvester to different positions on the tree considering two land types.

Figura 5. Tamanho médio dos danos causado por harvester em diferentes posições nas árvores considerando dois tipos de terreno.

It is possible to verify that the felling operation conducted on the different terrains did not present a statistical difference in the variable amount of damage by the Parallelism test $\left(\mathrm{T} 2=2.912^{\text {ns }}\right)$. This result indicates that the type of terrain does not affect the behavior of the curves for the conditions studied. It is important to note that the main damage was found at the base of the trees, followed by the trunk, without crown damage.

Although the terrain type did not show differences between the damage size averages, the greatest difference between damage at the base and trunk/shaft $(\mathrm{a}=-0.0016)$ and lower between the trunk/shaft and the crown $(\mathrm{a}=0.0009)$ was observed after applying the level test (base, trunk and crown). Regarding the third applied statistical test which aimed to verify whether the levels (base, trunk and crown) presented flat or inclined curves, it was found that they are not flat and that the levels affect the behavior of the curves (Flat $=147.5102 *$; Smooth $=87.5663 *$.

The dimensions of the damage found in the damaged trees varied between 2 and $810 \mathrm{~cm}^{2}$. Larger damage can make individuals more susceptible to pests and diseases and affect their future growth.

The greatest amount of damage to the remaining stand was found at the base of the trees, and all three tests found differences in relation to the type of terrain and the levels. This distribution can be seen in Figure 6 .

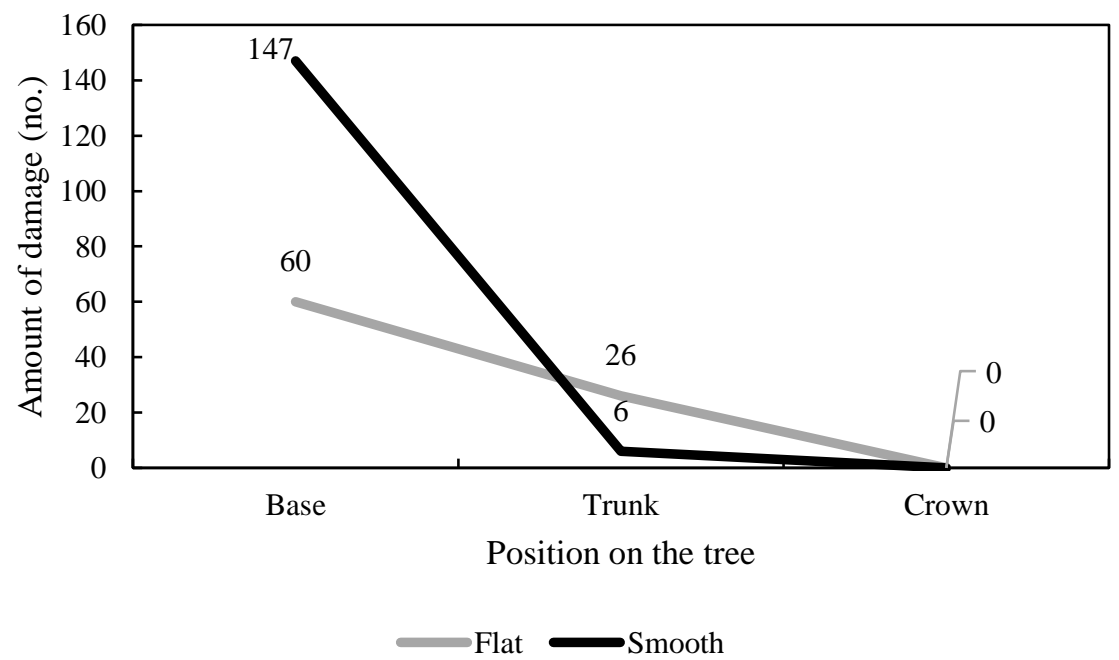

FLORESTA, Curitiba, PR, v. 50, n. 3, p. 1547 - 1554, jul/set 2020

Diniz, C. C. C. et.al.

ISSN eletrônico 1982-4688 
Figure 6. Distribution of the amount of damage caused by the harvester in thinning on the remaining trees of pine plantations.

Figura 6. Distribuição da quantidade de danos causados pelo harvester em árvores remanescentes de desbaste de plantios de pinus.

Of the 239 damage spots found, $86 \%$ were located at the base of the trees and $14 \%$ on the trunk/shaft. According to the type of terrain, $64 \%$ remained on smooth terrain and $36 \%$ on flat terrain, with a statistical difference by the Parallelism test. Although there is no difference between the average damage sizes, this result alerts us to the performance of forest cutting operations on land with a slope greater than $6^{\circ}$.

There is a higher incidence of damage at the base of the trees, which is the section with the highest commercial value. Thus, the results demonstrate the need for improvements in the operational forest cutting procedures with harvesters in conducting the thinning operation, avoiding the occurrence of damage to the trees and future losses. The location of the damage to the tree is shown in Table 2.

Table 2. Location of damage caused by the harvester in thinning to the remaining trees of pine plantations.

Tabela 2. Localização dos danos causados por harvester em árvores remanescentes de desbaste de plantios de pinus.

\begin{tabular}{ccc}
\hline Localização do dano & $\mathrm{N}^{\circ}$ Danos & Frequência (\%) \\
\hline & $88 \mathrm{a}$ & 37 \\
& $82 \mathrm{a}$ & 34 \\
\hline & $57 \quad \mathrm{~b}$ & 24 \\
\hline
\end{tabular}

Means followed by the same letter do not differ by the Tukey test, p-value $<0.05$.

The greatest intensity of damage occurred in the trees located to the left of the machinery traffic trail, meaning in the place where the wood was processed and stacked. Regarding the exposure side, it is noted that the sides of the trees showed more damage, with $37 \%$ and $34 \%$ respectively, both statistically equal to each other and with a difference from the other sides of exposure by the Tukey test ( $\mathrm{p}$-value <0.05). The injuries observed in the other axes were caused at the moment of displacing, processing and moving the head crane when cutting the individuals located in the selective thinning lines.

\section{DISCUSSION}

The percentage of remaining trees with injuries was considered high in this study when compared to the results obtained by Lineros et al. (2003), which presented $12.3 \%$ of damage in the first thinning of Pinus radiata at 10 years old, performed in the cut to lenght system with systematic removal of the $5^{\text {th }}$ row. Having studied the first combined thinning of pine trees at 10 years of age in $3 \times 2 \mathrm{~m}$ spacing in southern Brazil, with systematic cutting in the $5^{\text {th }}$ and $7^{\text {th }}$ lines, Cabral et al. (2018) found $13 \%$ and $17 \%$ of damage to the remaining trees, being lower than in this research. However, in another stand with a similar regime but with 12 years of age and systematic cutting in the $5^{\text {th }}$ line, Lopes et al. (2018) found higher percentages with $36.1 \%$ and $29.1 \%$ in the slopes from 0 to $10^{\circ}$ and 10 to $20^{\circ}$, respectively.

According to Vasiliauskas (2001), it is important to mention that the trunk sections of trees with a larger diameter are the most sensitive when affected by damage from thinning, with the possibility of not being able to close the lesion and it being attacked by fungi and insects; therefore, it can cause significant losses in the final product. Cabral et al. (2018) warned that minor damage found in pine trees is usually still amenable to closure (healing), preventing the occurrence of future phytosanitary problems in the trees.

The level of damage caused to the remaining trees in the stand may also be related to the skill and technique of the operators of the timber harvesting machines. Therefore, a way to reduce its incidence is to apply training and improvement to workers, as well as to develop specific procedures in thinning operations and minimize incorrect work procedures (LOPES et al., 2010).

The reduced space existing inside the stand affected the machine's reach for cutting trees during selective

FLORESTA, Curitiba, PR, v. 50, n. 3, p. 1547 - 1554, jul/set 2020.

Diniz, C. C. C. et.al.

ISSN eletrônico 1982-4688

DOI: $10.5380 /$ rf.v50 i3. 64331 
thinning, in addition to contributing to a long operating cycle time and reduced productivity (LOPES et al., 2017). This situation also applied in this study, given the similarities between the experimental areas of both studies.

In addition to the intrinsic operational aspects of each situation, it is recommended to carry out studies in relation to other factors which may affect damage occurring, as their intensity may be related to the time of year, the location and the physiological conditions of the stand (for example). Cabral et al. (2018) observed that it is difficult to avoid damage occurring to the remaining trees of a stand submitted to thinning caused by the movement of wood and machinery; however, Sirén et al. (2015) described the need to plan thinning and develop better working techniques in order to reduce damage occurrence to trees in forest stands.

Finally, this study corroborated other studies verified in the literature (LINEROS et al., 2003; CABRAL et al., 2018; LOPES et al., 2018), in which the position the current thinning was carried out in commercial pine stands being consolidated still causes a high percentage of damage to the remaining trees, mainly in the lower section of the trunk. This consolidates an urgency in the need to improve mechanized thinning procedures in order to definitely value the wood for future harvesting.

\section{CONCLUSIONS}

- There was significant damage caused by the harvester to the remaining pine trees by thinning, which can cause future damage to the stand.

- It was proven that the tree section which needs to be most alerted to was the base, as damage in greater intensity and dimensions caused by thinning with the wheeled harvester was observed.

- The number of damaged trees in the stand was considered high, indicating the need for improvements in operational procedures.

\section{REFERENCES}

BARBOSA, R. H. S.; FIEDLER, N. C.; MENDONÇA, A. R.; CHICHORRO, J. F.; GONÇALVES, S. B.; ALVES, E. G.; KUBOYAMA, F. A. Q. Análise técnica e econômica do desbaste em um povoamento de eucalipto na região sul do Espírito Santo. Nativa, Sinop, v. 3, n. 2, p. 125 - 130, 2015.

CABRAL, O. J. M. V.; LOPES, E. S.; FIEDLER, N. C.; DINIZ, C. C. C.; OLIVEIRA, F. M. Damage caused to the remaining trees of a pinus stand submitted to two mechanized thinning models. Floresta, v. 48, n. 4, p. 535$542,2018$.

\section{FORESTRY COMMISSION UK. Terrain Classification. 1996. Disponível em:} <http://www.biomassenergycentre.org.uk>. Acesso em: 01/12/2018.

JOHNSON, R. A.; WICHERN, D. W. Applied multivariate statistical analysis. Englewood Cliffs, N.J.: Prentice-Hall, 1982.

LINEROS, M.; ESPINOSA, M.; JIMENEZ, A. Daño a los árboles remanentes por sistema Harvester-Forwarder en Raleo Comercial de Pinus radiata D. Don. Revista Bosque, v. 24, n. 1, p. 87 - 93, 2003.

LOPES, E. S.; DINIZ, C. C. C.; SERPE, E. L.; CABRAL, O. M. J. V. Efeito do sortimento da madeira na produtividade e custo do forwarder no desbaste comercial de Pinus taeda. Scientia Forestalis, Piracicaba, v. 44, n. 109, p. $57-66,2016$.

LOPES, E. S.; OLIVEIRA, D.; SILVA, P. C.; CHIQUETTO, A. L. Avaliação do desempenho de operadores no treinamento com simulador de realidade virtual forwarder. Ciência Florestal, Santa Maria, v. 20, n. 1, p. 177 $186,2010$.

LOPES, E. S.; OLIVEIRA, F. M.; DROOG, A. Damage to residual trees following commercial thinning by harvester and forwarder in a Pinus taeda stand in Southern Brazil. Scientia Forestalis, v. 46, n. 118, p. 167-175, 2018 .

LOPES, E. S.; ROZA, B. L.; OLIVEIRA, F. M. Efeito de variáveis operacionais na produtividade de um harvester de pneus no desbaste de pinus. Floresta, Curitiba, v. 47, n. 4, p. 417 - 426, 2017.

OLIVEIRA, 2013. Revisão sobre a colheita de eucalipto em sistema de toras curtas (cut-to-length) no Brasil. Revista da União Latino-americana de Tecnologia, n.1, p. 42-54, 2013.

SANTOS, D. W. F. N.; FERNANDES, H. C.; VALENTE, D. S. M.; LEITE, E. S. Desempenho técnico, econômico e ambiental do harvester em distintas rotações do motor. Scientia Forestalis, v. 46, n. 118, p. 319-326, 2018.

FLORESTA, Curitiba, PR, v. 50, n. 3, p. 1547 - 1554, jul/set 2020

Diniz, C. C. C. et.al.

ISSN eletrônico 1982-4688

DOI: 10.5380/rf.v50 i3. 64331 
SCHNEIDER, P. R.; SCHNEIDER, P. Introdução ao manejo florestal. FACOS-UFSM, Santa Maria, 566 p., 2008.

SEIXAS, F.; BATISTA, J. L. F. Comparação técnica e econômica entre harvesters de pneus e com máquina base de esteiras. Ciência Florestal, Santa Maria, v. 24, n. 1, p. 185 - 191, 2014.

SIRÉN, M.; HYVÖNEN, J.; SURAKKA, H. Tree Damage in Mechanized Uneven-aged Selection Cuttings. Croatian Journal of Forest Engineering, v.36, n.1, p.33 - 42, 2015.

SPINELLI, R.; NATI, C. A Low-Investment fully mechanised operation for pure selection thinning of pine plantations. Croatian Journal of Forest Engineering, v. 2, n. 30, p.89 - 97, 2009.

VASILIAUSKAS, R. Damage to trees due to forestry operations and its pathological significance in temperate forests. Journal of Forestry, v. 74, n. 4, p. 319 - 336, 2001. 